\title{
Elementary school students' mathematical connection in problem-posing activities
}

\author{
Mohammad Archi Maulyda *, Awal Nur Kholifatur Rosyidah, Vivi Rachmatul Hidayati \\ Elementary School Teacher Education Study Program, Universitas Mataram, West Nusa Tenggara, \\ Indonesia \\ *Correspondence: archimaulyda@unram.ac.id \\ (C) The Author(s) 2022
}

\begin{abstract}
The ability of mathematical connections possessed by students can be seen from the ability of students to compile math problems. This study aims to determine the type of mathematical connection made by elementary school students in problem-posing activities. The research was conducted using a qualitative descriptive method. The participants were 34 fifth grade students (male $=16$ female $=18$ ) of one of the public elementary schools in Mataram, West Nusa Tenggara. Data were collected from the results of student work and interviews. The analysis was carried out qualitatively according to the indicators of the complexity of the problem through problem posing learning. The results showed that there were four types of mathematical problems and their relatedness that occurred in student problem-posing activities, including (1) unsolvable math problems, (2) incorrectly solved math problems, (3) neglected math problems contextual information, and (4) mathematical problems that have complexity and relevance. Based on these results, it can be recommended for further research to determine strategies to improve students' mathematical connections in problem-posing activities.
\end{abstract}

Keywords: elementary school; mathematical connection; problem-posing 


\section{Introduction}

The National Council of Teachers of Mathematics (NCTM) in Principles and Standards for School Mathematics stated that mathematics teaching and learning should support students' development of mathematical connection skills. It is essential because a good mathematical connection will help students understand the mathematical concepts (Hendriana et al., 2014; Metha et al., 2018; Kenedi et al., 2019). When the students can connect concepts, facts, and procedures in mathematics, they will look at the bigger picture of mathematics and construct a deep understanding of it. Without a mathematical connection, the students will learn mathematics as separated knowledge (Kenedi et al., 2019). The mathematical connection is also crucial in problem-solving activities (Budiasih \& Wonorahardjo, 2017; Rahman \& Ahmar, 2017).

Unfortunately, some previous studies showed that the students' mathematical connections are low (Young et al., 2018). It can be seen, for instance, in a study about mathematical connection in linear equations conducted by Asiyah et al. (2017) that found only $55 \%$ of students who able to make connections between related topics, $40 \%$ of students able to make the connection between mathematics and other fields of knowledge and $2 \%$ students able to connect mathematics and real-life application. The study of Yuliani et al. (2018) in probability topic found that $41 \%$ of students could see the connection between related topics, while $56 \%$ saw the connection between mathematics and other subjects, and $55 \%$ of students were able to connect mathematics and real life. Furthermore. Solórzano (2014) investigated the mathematical connection in algebra and Pythagoras Theorem. It was found that $50 \%$ of students were not able to solve the problem due to internal connection difficulties, while $67 \%$ of students were due to external connection.

The previous studies also investigated the relation between mathematical connection and problem-solving abilities (Nägele et al., 2014; Isfayani et al., 2018). It was found that the students with high skills were able to construct a complete internal and external mathematical connection (Kamid et al., 2020). Setiawan et al. (2017) stated that the students with good problem-solving abilities had a good structure sense. The findings are also in line with Asiyah et al. (2017) that the students with good problem-solving ability could make a complete mathematical connection in solving arithmetic series and sequences. From those studies, it can be concluded that the students with poor problem-solving abilities could not create a complete mathematical connection.

Despite its trend in problem-solving abilities, a limited number of studies focus on the relationship between mathematical connection and problem posing. In fact, problem-solving and problem-posing are not totally different in terms of cognitive activities performed, e.g., both of them need mathematical connections (Nurjaman \& Sari, 2017). In problem-posing, the students are intentionally guided to find connections among information. Therefore, making the mathematical connection is one of the essential skills in problem-posing (Kar, 2016). Problemposing also can be seen as an assessment tool to assess students' cognitive skills and conceptual understanding by investigating their mathematical connections (Kartika \& Tandililing, 2016). 
Therefore, problem-posing activities can explore the students' mathematical connections (Yosopranata et al., 2018). Moreover, it can be used to evaluate students' comprehension of mathematics (Ramadhani \& Kusuma, 2020).

Problem posing can be employed to evaluate students' mastery in mathematics, introduce new learning topics, upgrade the difficulty level of mathematics application, and create connections across mathematical topics and the implementation of mathematics in daily life (Rosyana et al., 2018). In implementing problem posing, a teacher needs to consider the types of activity used. Therefore, in the present study, we created a semi-structured activity in which the student would be encouraged to complete the given information and connect with other mathematical concepts.

We conducted a preliminary study related to the mathematical connection in the problemposing activity of the 72 five-grade students of SDN 26 Ampenan, Mataram, divided into two classes. Elementary students were chosen as subjects because they are in the age of proper operation cognitive stage, where people start to think logically and can do mathematical abstraction Maulyda et al. (2020). The instrument of the study was a semi-structured problem posing-based worksheet in the Pythagoras theorem. The task is to pose a problem related to the following Figure 1.

A

$8 \mathrm{~cm}$

$\mathrm{C}$

B

Figure 1. Semi-structured question in Preliminary Study

To pose a problem, the students need to apply several mathematical concepts, e.g., proportion, algebra, Pythagoras theorem, and the area of a triangle. Those concepts are connected procedurally where the students can implement the further procedure. For instance, to determine the length of $(\overline{A B})$ and $(\overline{B C})$ by using the Pythagoras theorem and then find the length of $(\overline{B D})$ using the area of triangles concept. One of the examples of students' responses can be seen in the following Figure 2. 


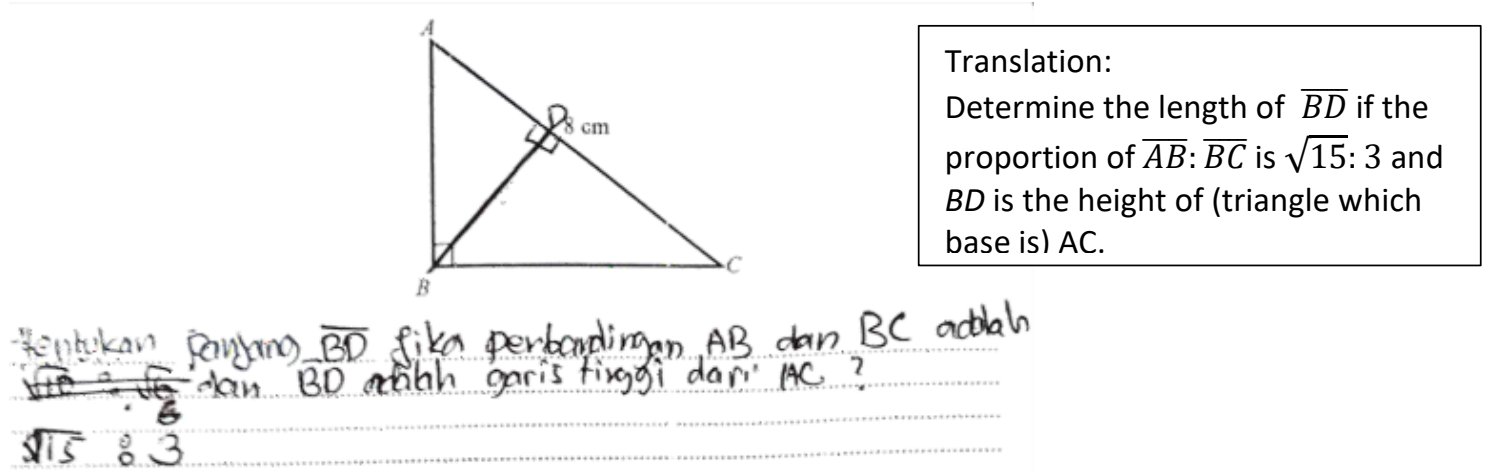

Figure 2. Example of students' problem

From student's responses in Figure 2 it can be seen some information are missing, i.e., how they decide to the make the proportion of $(\overline{A B}):(\overline{B C})$ is $\sqrt{15: 3}$. Perhaps, it was started from $|\overline{A B}|^{2}:|\overline{B C}|^{2}=64$, then choose $|\overline{A B}|^{2}$ and $|\overline{B C}|^{2}$ which are 40 and 24. Later, $(\overline{A B})$ and $(\overline{B C})$ are $2 \sqrt{10} \mathrm{~cm}$ and $2 \sqrt{6} \mathrm{~cm}$ respectively. To create a more complex calculation in the problem, the student wrote $(\overline{A B}):(\overline{B C})=\sqrt{15: 3}$. The choice of number showed the students' mathematical connection between number and geometry concepts.

Based on Ghofur and Rachma's (2021) problem taxonomy, the mathematical problem proposed in Figure 2 is considered a problem at the synthesis level. It means it has the highest complexity where in formulating the problem, the student needs to connect some mathematical ideas that have been learned (Metha et al., 2018). Furthermore, Polya in Yosopranata et al. (2018) stated that a simple problem is appropriate for simple complex while a complex problem can be used to investigate complex concepts or connections between concepts, procedures, and reasoning strategies. The statement is in line with Tsai (2007) that the complexity of the problem can be used to evaluate the sophistication of mathematical relations embedded in it. Hence, a complex mathematical problem gave better opportunities to gain more information related to students' mathematical connections. Knowing students' way of thinking is the core of a teacher's professional development. Hence, the present study is aimed to give a meaningful explanation of mathematical connection in problem-posing since, according to Solórzano (2014), it is hardly discussed in other studies.

Based on the explanation above, it can be seen that deepening the analysis of students' mathematical connection abilities is important. When students do problem-posing activities, the ability of students to connect mathematical materials becomes a very important factor. When students assemble mathematical concepts in one problem-solving problem formulation, it is possible for this mathematical connection process to run. Thus, the researcher assumes that students can improve their mathematical connection skills through problem-posing activities. It will directly impact increasing students' ability to solve a problem because a problem tends to require a combination of several mathematical concepts to solve. 


\section{Methods}

The study aims to describe the mathematical connection of Elementary School students in geometry topics using problem-posing activities. The type of study is descriptive qualitative. This type of research was chosen because the research paradigm follows the type of data presented and how the researcher presents the data. The data obtained are descriptive analyses of the results of making questions carried out by students, so this type of research is the right research paradigm - the present study employed a collaborative model between researchers and one mathematics teacher in the fifth grades classroom. The benefit of the collaborative work in the research is that the researchers can adjust the flow of the study based on the observation. In this case, the teacher will act as a teacher while the researcher only becomes an observer in problem-posing activities carried out by the teacher in the classroom. The researchers' roles were to observe, make and execute the plan, gather and analyze data. All stages of the research, formulated by researchers based on the results of the modification of the qualitative research flow formulated by Creswell (2012).

The data relating to the spoken and written words and students' behavior were gathered from observation (Creswell, 2012). To choose the subject of the study, 34 candidates in V grades were asked to pose a mathematical problem which was analyzed based on problem complexity based on Calor et al. (2019) as in the following Table 1.

Table 1. Problem Complexity Indicators

\begin{tabular}{cll}
\hline No & \multicolumn{1}{c}{ Category } & \multicolumn{1}{c}{ Indicator } \\
\hline 1 & Conceptual Complexity & Number of related topics addressed in the problem. \\
2 & Mathematical Complexity & Different possible solutions available. \\
3 & Intellectual Complexity & Analysis needed to solve the problem. \\
4 & Representational Complexity & $\begin{array}{l}\text { The solution can be represented using diagrams or } \\
\text { graphics. }\end{array}$ \\
& & The level of context used in the problem. \\
\hline
\end{tabular}

After analyzing the candidate's responses, it was found that students' answers can be classified into four categories, i.e.: (1) mathematical problem that cannot be solved, (2) mathematical problem that was not correctly solved by the problem poser, (3) mathematical problem that diminishes the contextual information and (4) mathematical problem that can be analyzed in term of its complexity and mathematical connection. The mathematical complexity was analyzed using the following scheme, as seen in the following Figure 3. 


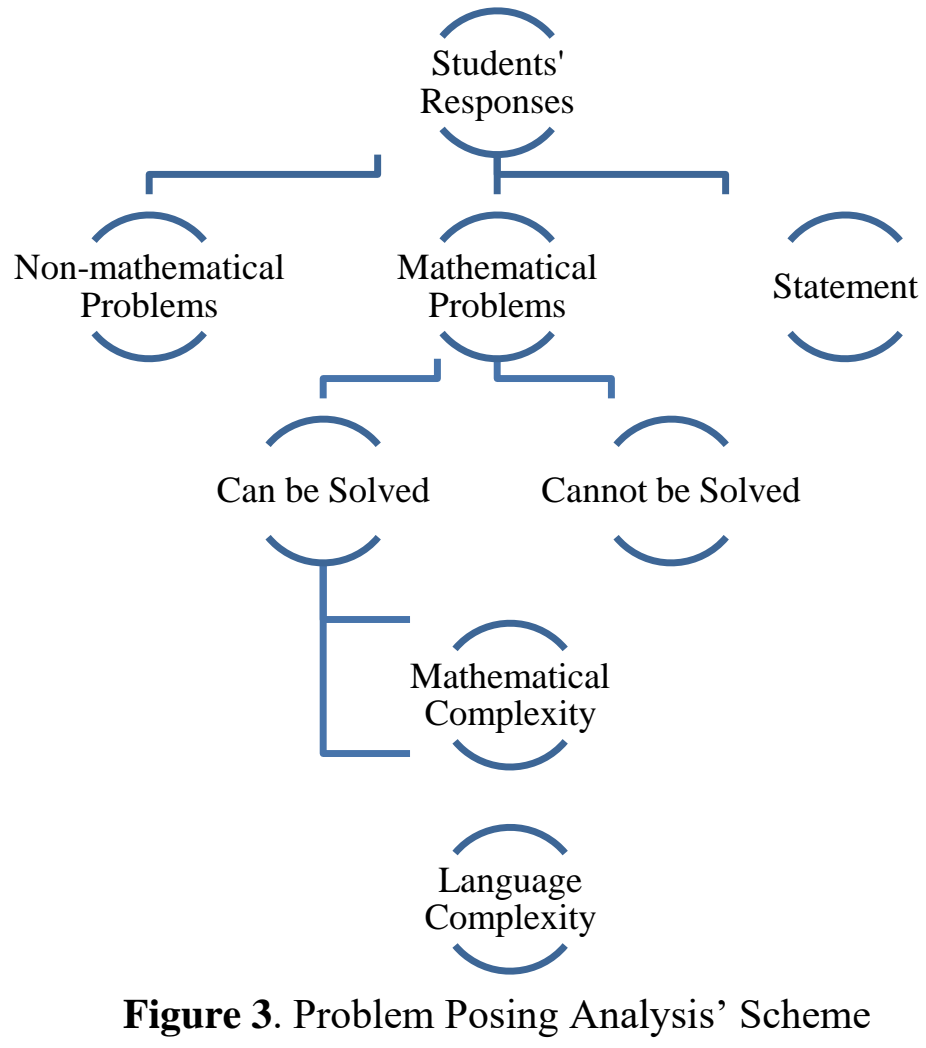

In Figure 3 above, it has been explained that the analysis process will be reduced based on three essential things, namely non-mathematical problems, mathematical problems, and only problem statements made by the subject. The results of the work analyzed are the results of questions that fall into mathematical problems. After that, the analysis results will be carried out based on problems that can be solved and problems that cannot be solved. The mathematical connection of the students will be analyzed from students' responses in posing the mathematical problems and from the interview. The students' mathematical connection will be evaluated using a modified mathematical connection of NCTM (2000) as in the following Table 2.

Table 2. Mathematical Connection Indicators

\begin{tabular}{lll}
\hline \multicolumn{1}{c}{ Internal Mathematical Connection } & External Mathematical Connection \\
\hline a) The relation across mathematical & a) & Using symbols, diagrams or other \\
concepts. & mathematical representation to explain \\
the aplication of mathematics in other \\
b) The relation between & fields. \\
mathematical procedures or & b) & $\begin{array}{l}\text { Applying mathematics in real world } \\
\text { context. }\end{array}$ \\
\hline
\end{tabular}

\section{Results and Discussion}

The 34 participants were asked to create a mathematical problem and solve it by themselves with the following information: (i) a garden which shape resembles a circle; (ii) in the middle of the garden, there is a fountain with a circular shape; and (iii) the length of the fence of the garden is $314 \mathrm{~m}$. In general, there are four types of problems posed by students, 
which are: a problem that cannot be solved, a problem that is incorrectly solved, a problem with missing contextual information, and a problem that can be analyzed in terms of its complexity and connection.

Based on the initial analysis results conducted on 34 participants who were given assignments, only 15 of them were included in the category of mathematical problems. While the remaining 19 did not meet the expected mathematical problem criteria. After that, from 15 participants, 4 participants were chosen who could represent the pattern of work results from 15 other participants. The four participants represent categories, (1) Mathematical problem that cannot be solved; (2) Mathematical problems that incorrectly solved; (3) Mathematical problems that dismiss the contextual information; (4) Mathematical problems that can be analyzed based on its complexity and connection.

\section{Mathematical problem that cannot be solved}

The following problem from student with code JG provides the example of mathematical problem that cannot be solved due to incomplete information.

A garden with a pool is observed from top. The garden is surrounded by a fence which length $314 \mathrm{~m}$. If a garden of rose is made behind the garden of orchid, what is the perimeter of rose garden?

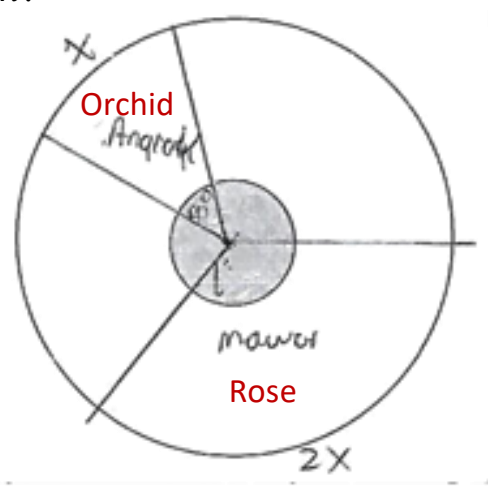

Figure 4. JG's illustration of the proposed problem

In figure 4, student JG provided the illustration that the degree of the orchid garden is $60^{\circ}$ and the proportion of perimeter orchid and rose garden is 1:2. After formulating the problem, $\mathrm{JG}$ tried to solve the problem as can be seen in the following Figure 5.

Informations: diust: $h=3 \mathrm{~cm} \mathrm{~m}$

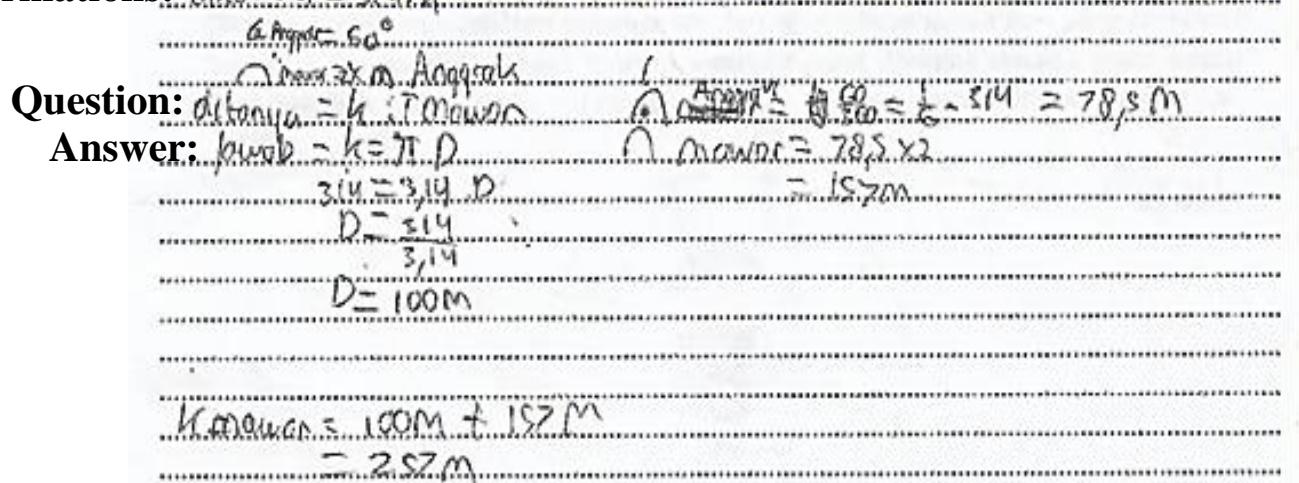

Figure 5. JG's problem-solving 
In Figure 5, JG incorrectly determined the geometrical objects whose length needs to be calculated. Based on JG's response, we illustrated the following Figure 6 (a) \& (b) to show the miscalculation. The red line in Figure 6(a) is the length of the line calculated by JG; meanwhile, the blue line in 6 (b) is the line that is supposed to be calculated.

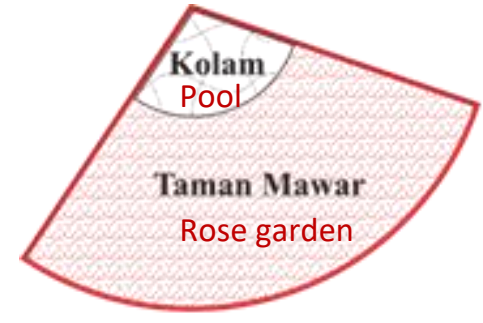

(a)

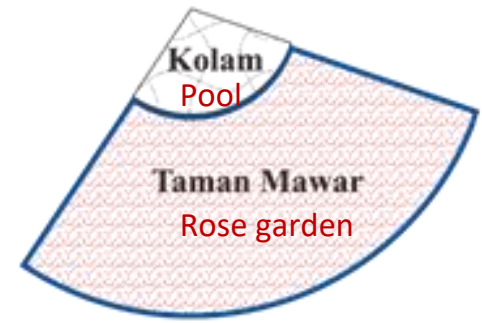

(b)

Figure 6. Comparison between what is done and what is supposed to be done

From Figure 6, it can be observed that the perimeter of the rose garden should not go forward until the end of the pool. The student's error might have happened due to the lack of understanding of the topic of two-dimensional geometry. The results of interviews conducted with JG are as follows:

$P \quad: \quad$ What do you understand from this problem situation?

$J G \quad: \quad$ It wants to make a pool in the backyard. The pool is circular

$P \quad: \quad$ What do you imagine from this situation?

$J G \quad: \quad$ There is a pond in Mr.'s yard like this picture. (While pointing at the picture on the completion sheet)

JG participant observed that a pool with a circular base is a tubular shape. This review shows that JG Students make internal and external mathematical connections simultaneously. External mathematical connection is done when JG students see that the pool represents the shape of a tube space. In contrast, the connection between the concept of a circle and a tube shows the internal mathematical connection. From several concepts related to the tube, JG students used the concept of volume in formulating problems. JG students understand that the volume of a cylinder is the product of the area of the base and the height of the cylinder. Furthermore, JG students interpreted the volume of the tube as the volume of water to fill the pool, the area of the base of the tube as the bottom area of the pool, and the height of the tube was the depth of the pool. 


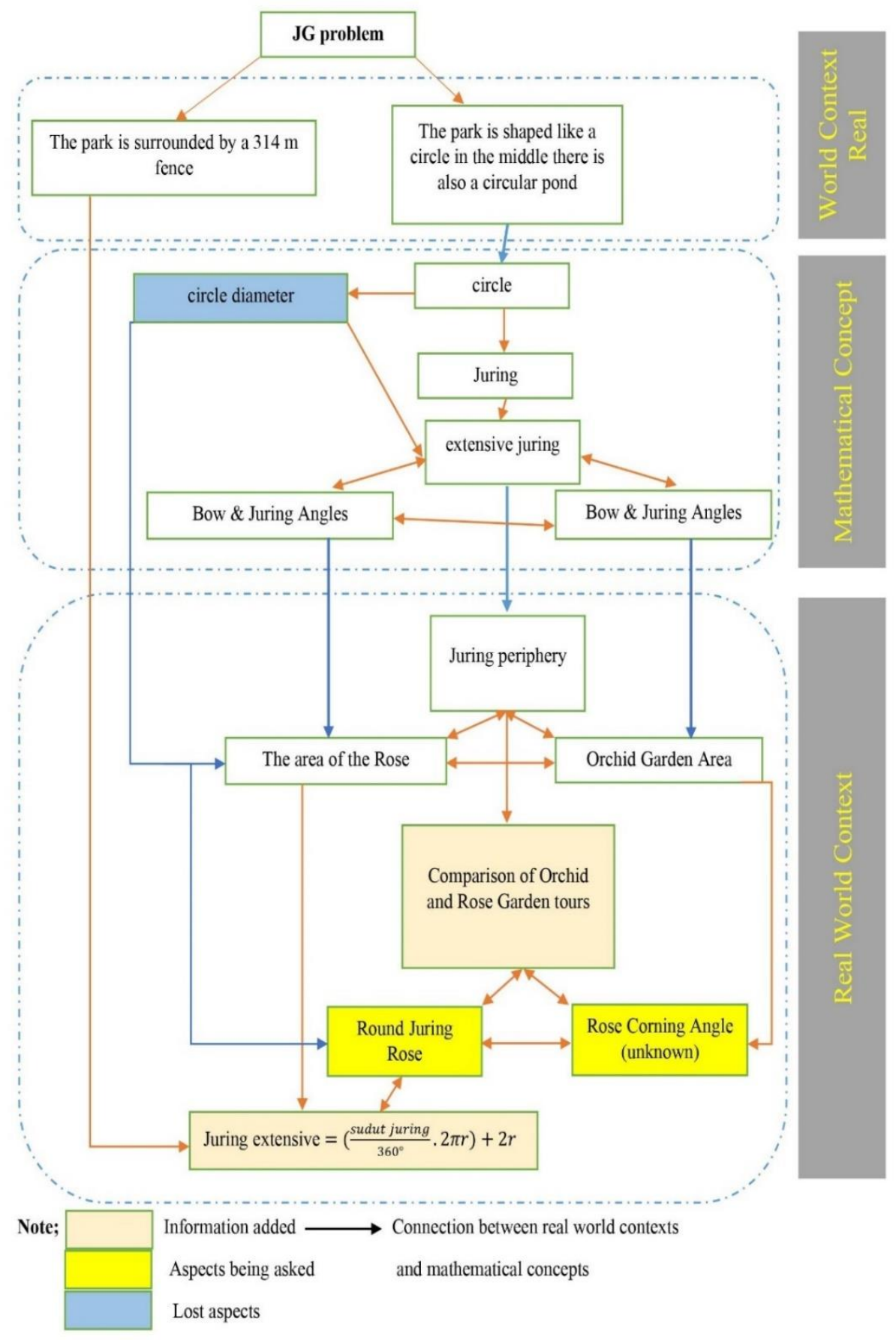

Figure 7. JG's mathematical connection

Based on Figure 7, the mathematical connection occurs after the JG subject understands and represents the given contextual situation. The situation given is in the form of two mathematical information: a rectangular land and a pond with a circular base. An internal mathematical connection occurs between the concept of a circle and a tube where the pool with the base of the circle is in the form of a tube space. JG subjects pay attention to the pool object, which is a representation of the shape of the tube space and its attributes, such as the base, the 
height of the tube, and the volume. These attributes are then translated into the real-world context into pool bottom area, pool depth, and pool volume. The subject of JG asked a question, namely determining the depth of the pool so that the attributes of the base area and the volume of the pool become information that needs to be presented in mathematical problems. The basic area attribute is developed by associating its value with the value of the yard area. In contrast, the pool volume is developed by presenting its value implicitly in the volume of water poured in the pond. The external representation of JG was incorrect. Hence, JG was missing the vital information needed to complete the problem, i.e., the pool's diameter, which makes the circumference of the sector that represents the rose garden cannot be found. According to Nägele et al. (2014) \& (Prasetyo et al. (2017), the incomplete information in students' work, as in JG, showed a low mathematical connection skill.

$P \quad: \quad$ Simply you add information on the area of the pool base and its volume. What is the purpose?

$J G \quad: \quad$ To find the depth

$P \quad: \quad$ What is the relationship between depth and the two elements?

$J G \quad: \quad$ It will be in the form of a pool tube.

$P \quad: \quad$ What's the relationship?

$J G \quad: \quad$ Area of base times height equals volume

JG subject decide which story to use in the problem, namely by adding information about the bottom area of the pool and the volume of water that is filled into the pool. The area of the pond in this problem is expressed by a number that states the proportion to the area of the backyard. JG students implicitly give the value of the bottom area of the pool because JG students want a more unique formulated problem.

\section{Mathematical problem that incorrectly solved}

Unlike the previous case, the problem in the second case is mathematically solvable, but the student who posed it did not solve it correctly. In our study, the case happened to students with code DZ. Consider the following problem.

Andi, Budi, Chris will participate in three rounds running race in a circular track. Andi takes inside track, while Budi $i$ the middle and Chris outside with distance $10 \mathrm{~m}$ each(see figure 8). They run with the same speed of $1 \mathrm{~m} / \mathrm{s}$. Find the total length of track of each person. Who will win the race? Calculate the time needed!

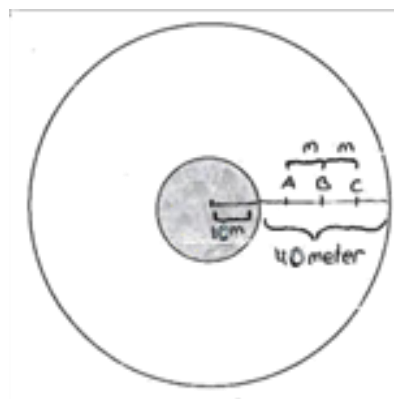

Figure 8. DZ's illustration of the proposed problem 
From the use of the information given, DZ convert the length of the garden's fence into the diameter of the garden. Next, from the given problem, the question about the winner actually needs no calculation. From the given illustration in Figure 8, and will win the race because he has the shortest track. The solution from DZ can be seen in the following Figure 9.

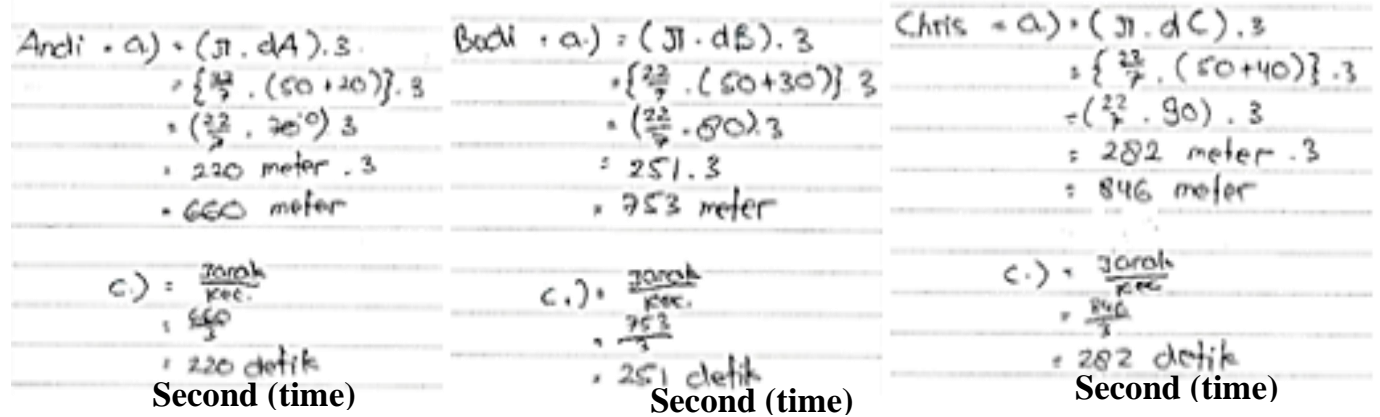

Figure 9. DZ's problem solving

Figure 9 shows DZ's incorrect answer in determining the diameter of each track. The diameter of the track of Andi, Budi, and Chris are $40 \mathrm{~m}, 60 \mathrm{~m}$, and $80 \mathrm{~m}$, respectively. DZ also made an error in calculating the time needed by each runner. Based on the proposed problem, the speed is $1 \mathrm{~m} / \mathrm{s}$, and it is not supposed to change even though the runner runs for three rounds. This finding is in line with the study of Young et al. (2018) \& Asiyah et al. (2017) that a mathematical problem that involves more than one mathematical topic needs a good mathematical connection. The results of interviews conducted with DZ are as follows:

$P \quad: \quad$ What information did you add to create trouble earlier?

$D Z \quad$ : What I added was a description of the area. Pool area but in the form of a puzzle. That's $1 / 3$ of the page.

$P \quad: \quad$ Does the pool have an area?

$D Z \quad$ : $\quad$ Yes... the pool area.

$P \quad$ : What area is it? What is the wall?

DZ : Oooo... this... bottom of the pond

$P \quad$ : So the area in question is the area of the bottom of the pool. OK. Why did you call it a riddle?

$D Z \quad$ : Since the value is unknown, you have to find it yourself. According to this information, it is known that the pool area is $1 / 3$ of the yard area. So look for it from the relationship earlier.

Mathematical problems formulated based on this situation are pretty complex problems. DZ students tend to formulate complex problems requiring several steps to reach a solution. The strategy of DZ students in formulating complex mathematical problems is to link some of the information in the situation, for example, stating the bottom area of the pool through the proportion to the backyard area. Another strategy of DZ Students is to develop simple mathematical problems by adding contextual situations. The following snippet of the interview transcript shows how this mathematical problem has become more complex.

The transition from the real-world context (given situation) to mathematical concepts in the form of geometric objects such as tubes and annulus flat shapes. These geometric objects are then analyzed for attributes or mathematical concepts attached to them, such as the concepts of area, volume, and the quantities that influence them. The connection between these mathematical concepts also includes observations of the attributes attached to a mathematical 
concept Urbaś (2016) and contains control questions about what operations and techniques can be used in mathematical problems (Rohendi \& Dulpaja, 2013). The research subject's review of the operation that applies between the volume of the tube, the area of the base, and the height, which is then continued by relating the area of the base to the area of the page, is seen as a series of procedures used in formulating the problem. This shows that the research subjects can associate one operation with another operation. It is in line with the opinion of Hasselmann Bettin et al. (2020), who propose five types of connections, one of which is the connection of a specific operation to perform other operations.

\section{Mathematical problem that dismisses the contextual information}

The following example showed the mathematical problem which not considering the contextual information from a student with code; EK.

What is the area of smaller circle if the comparison of large and small circle is $4: 2$ and the circumference of the large circle is $314 \mathrm{~m}(\pi=3.14)$ ?

The problem from EK is not using any contextual information given. Moreover, the garden and fountain context has been changed into large and small circles. However, there is a mathematical ambiguity when EK mentioned the comparison of the large and small circles without referring to what part of the circle was used to compare, e.g., the diameter, the area, and others. The transition from real-world context to mathematical concepts using geometrical objects, such as circle, cylinder, sphere, etc., is a part of mathematical connection, which is the ability to observe the attributes of the mathematical objects Badjeber and Fatimah (2015) and the appropriate procedures to solve the given mathematical problem (Yosopranata et al., 2018).

Volume information in the quantity of water poured into the pond is 300,001 liters. Interestingly, the selection of numbers used by EK students to express the number of volumes of water poured, namely the number 300,001. EK students expect the number 300,000 (stating the volume of the pool when it is full), which will be operated with the number of the bottom area of the pool so that the depth of the pool is an integer. To produce a unique problem with an unusual solution, EK students add the number 1 as the volume of spilled water on the number 300,000 so that 300,000 represents the volume of water poured with the description spilled.

In solving this problem, to get the maximum depth, the volume of spilled water must be as minimal as possible so that the maximum pool volume (in whole numbers) will be obtained. Regardless of the expected pool depth results in the form of integers, researchers dig deeper into the quantity of water that must be spilled in order to obtain the maximum depth. The following interview transcript shows students' understanding of the nature of the addition of numbers. It shows that EK students can apply the concept of numbers to other mathematical concepts.

$P \quad: \quad$ If the volume of water poured is 300,002 liters, what volume of water must be spilled to maximize the depth of the pool?

EK : $\quad$ Must be 1 liter sir. But the depth is 3,00001 and if you round it up, it's 3 meters too, sir.

$P \quad$ : But mathematically it's still a maximum (greater) 3,00001 than 3, right? 


\begin{tabular}{|c|c|c|}
\hline$E K$ & & Yes sir. \\
\hline$P$ & & $\begin{array}{l}\text { If the volume of water poured is } 300,000,8 \text { liters, what volume of water } \\
\text { must be spilled? }\end{array}$ \\
\hline$E K$ & & $\begin{array}{l}0.8 \text { liter sir. Anyway, it has to be as little as possible so that the volume } \\
\text { of the pool is integer and maximum }\end{array}$ \\
\hline$P$ & & $\begin{array}{l}\text { If the volume of water poured is } 300,002 \text { liters, what volume of water } \\
\text { must be spilled to maximize the depth of the pool? }\end{array}$ \\
\hline$E K$ & & $\begin{array}{l}\text { Must be } 1 \text { liter sir. But the depth is } 3,00001 \text { and if you round it up, it's } 3 \\
\text { meters too, sir. }\end{array}$ \\
\hline
\end{tabular}

Researchers asked EK students to solve mathematical problems formulated by themselves with the aim of whether the formulated problems could be solved or not. The mathematical problem described above results from correction after EK students complete the problem on the solution sheet. The corrections made were (i) changing the question from the minimum depth to the maximum depth, and (ii) changing the volume of water poured several times from 301 liters to 30,001 liters and then to 300,001 liters. The minimum depth question was changed after the researcher asked the maximum volume and minimum height written on the solution sheet.

In the mathematical problem formulated based on the situation I, students made an external mathematical connection which was indicated by the emergence of the concept of a tube in a mathematical problem to represent the shape of a pool based on a circle. In formulating a mathematical problem based on situation II, the research subject made an external mathematical connection indicated with a representation between the annulus area and the pool edge area. The external mathematical connection also occurs when the research subject understands situation III. The information associated with the mathematical concept is a pool with a circular base in the form of a tube and the edge of the pool in an annulus flat shape. In this case, the representation of the tube and the annulus flat shape in everyday life is an external mathematical connection, namely the relationship between mathematical ideas and the real world or everyday life Young et al. (2018), where this representation provides a good context in formulating problems. The transition from real-world contexts to mathematical concepts is also proposed by Asiyah et al. (2017) in terms of connections from problematic situations to mathematical content and Nägele et al. (2014) in real-world situations to real-world problems statements and then to mathematical models. Furthermore. Prasetyo et al. (2017) state that this transition requires an understanding of real-world problems and possible ways to be mathematical.

\section{Mathematical problem that can be analyzed based in its complexity and connection}

The next type is the mathematically correct problem, solved correctly, and considers the given contextual information. The example shown by the student with code $\mathrm{CP}$ can be seen in the following problem.

Mr. Syaiful will build a pool in the land behind his house which size $15 \mathrm{~m} \times$ 20.. The pool is in circle shape. It is known that the area of the base of the pool is third of the area of the land. Mr. Syaiful fulfill the pool with 300.001 litre of water and it was spill out. Find the depth of the pool if its volume is integer (in litre). 
The problem of $\mathrm{CP}$ connected all of the information given. $\mathrm{CP}$ were also able to solve the problem corectly. The following Figure 10 showed CP mathematical connection.

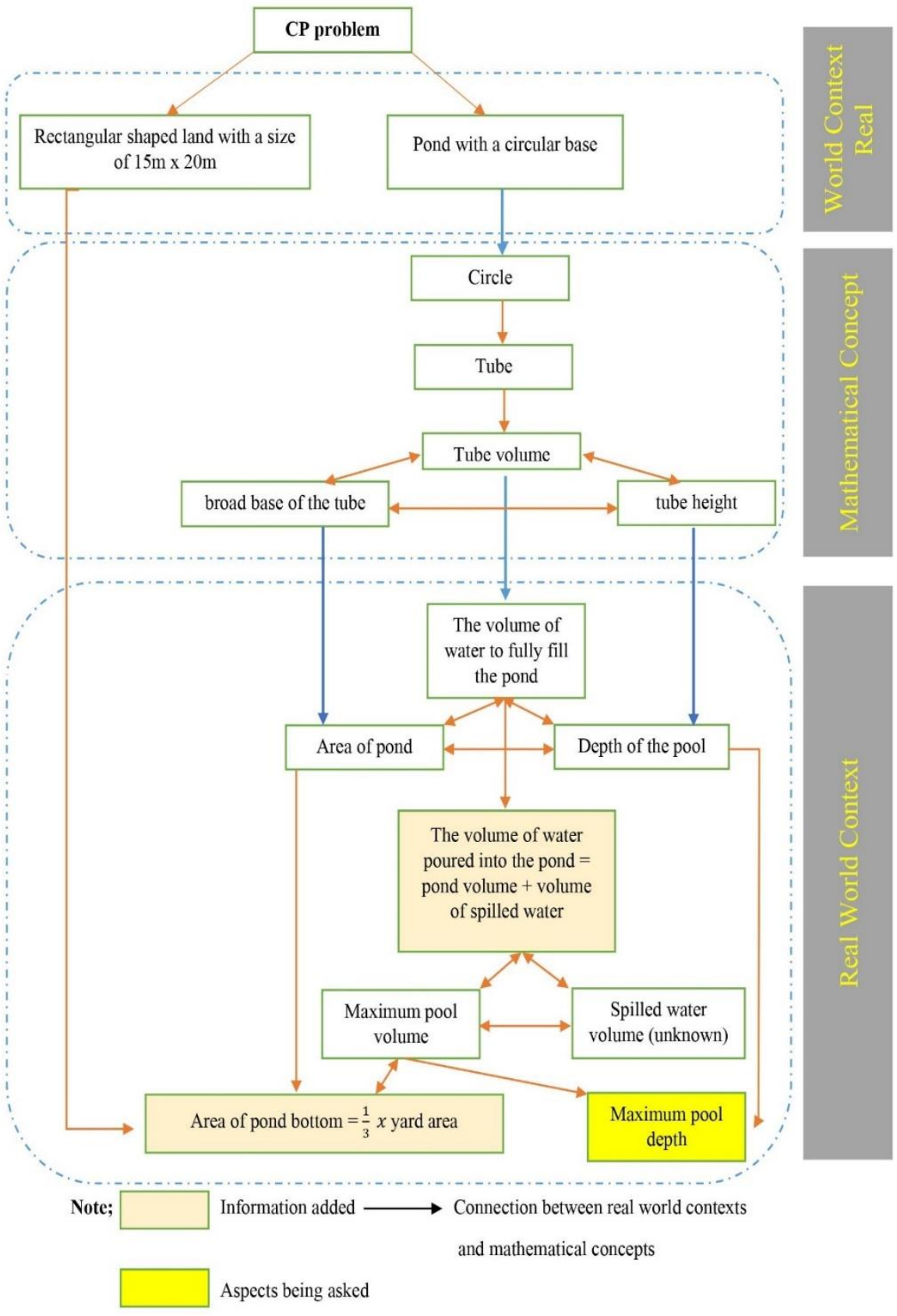

Figure 10. CP's mathematical connection

According to Figure 10, CP was able to understand and represent the contextual situation given in the task. CP considered the shape of the land is a rectangle, and the shape of the pool was a circle. The mathematical connection was made by connecting the shape of the pool, a cylinder, with its attribute (volume, height, base, etc.). At the end of the solution, it was translated again into the context of the pool. An internal mathematical connection occurs between the concept of a circle and a tube, where the pool with the base of the circle is in the form of a tube space. CP students pay attention to the pool object, which is a representation of the shape of the tube space and its attributes such as the base, the height of the tube, and the 
volume. These attributes are then translated back into the real-world context into pool bottom area, pool depth, and pool volume. CP students ask questions, namely determining the depth of the pool so that the attributes of the base area and the volume of the pool become information that needs to be presented in mathematical problems. The basic area attribute is developed by associating its value with the value of the yard area, while the pool volume is developed by presenting its value implicitly in the volume of water poured in the pond.

The transition between mathematical concepts to real-world application is called demathematization (Sari et al., 2018). The students re-use the transition through external mathematics to formulate a mathematical problem (Berizzi et al., 2017). The mathematical problem was designed by considering the sentence structure, numbers, and mathematical concepts, as also found by Murdiyani et al. (2013). This transition from real-world contexts to mathematical concepts occurs through external mathematical connections where students understand a contextual situation. It follows the opinion of Badjeber and Fatimah (2015), which states that problem-posing is an activity of understanding situations (grasping situations) where understanding a situation is seen as a search for questions and problems that arise from a mathematical or non-mathematical situation. Yosopranata et al. (2018) also argue that problemposing goes through the initial stages of accepting, which occurs when students read and understand the given situation.

\section{Conclusion}

Based on the external and internal mathematical connection that happened when the students formalize the problem, we can distinguish the transition into three forms, i.e.: (1) external mathematical connection in transition between real-world to mathematical concepts, (2) internal mathematical connection across mathematical concepts and (3) external mathematical connection in transition between mathematical concepts to a real-world context. In this study, the first transition is happened when the students try to understand the contextual situation and represent it to the geometrical objects. For instance, the problem in the real world is investigating a pool that resembles a cylinder in mathematics. Then the students observe all attributes related to the object, e.g., the volume, surface area, height, and base area. The second transition happened when the students made connections among the attributes of the geometrical object, i.e., the relation between the height and the volume. Later in the third transition, the students interpret the calculation result with the real-world situation. For instance, the height of the cylinder is actually the depth of the pool.

The mathematical connection performed by the students showed the problem-posing activities involving the skills to identify the relation between mathematical concepts and procedures in mathematics and the context outside mathematical objects. Technically, mathematical connections support the students in making decisions related to the structure of the sentences and the difficulties level of the mathematical problem. It helps the students to make sense of a complex mathematical problem. Students who can formulate complex problems identify research findings regarding mathematical connections that occur through real-world context transitions-mathematical concepts. Future studies need to use more 
significant research subjects with varying degrees of difficulty of the formulated problems to clarify whether the three transitions also occur.

\section{Conflicts of Interest}

The authors declare that no conflict of interest regarding the publication of this manuscript. In addition, the ethical issues, including plagiarism, misconduct, data fabrication and/or falsification, double publication and/or submission, and redundancies have been completely by the authors.

\section{References}

Asiyah, S. N., Suyitno, A., \& Safa'atullah, M. F. (2017). Mathematical connection in terms of student learning styles of the tenth grade on the REACT model learning. Unnes Journal of Mathematics Education, 6(2), 205-214.

Badjeber, R., \& Fatimah, S. (2015). Peningkatan kemampuan koneksi matematis siswa SMP melalui pembelajaran inkuiri model Alberta [Improving the mathematical connection skills of junior high school students through the Alberta model of inquiry learning]. Jurnal Pengajaran MIPA, 20(1), 18-26. https://doi.org/10.18269/jpmipa.v20i1.557

Berizzi, G., Di Barbora, E., \& Vulcani, M. (2017). Metacognition in the e-learning environment: A successful proposition for inclusive education. Journal of E-Learning and Knowledge Society, 13(3), 47-57.

Bettin, A. D., Leivas, J. C. P., \& Mathias, C. V. (2020). A geometric connection: mental images, visualization and mathematical register. Amazona: Journal of Mathematical Education, 16(36), 114-127. https://doi.org/10.18542/amazrecm.v16i36.7301

Budiasih, E., \& Wonorahardjo, S. (2017). The effectiveness of WhatsApp on problem posing learning towards students' motivation and cognitive learning. Jurnal Pendidikan Sain, 5(4), 135-141.

Calor, S. M., Dekker, R., Drie, J. P. Van, \& Zijlstra, B. J. H. (2019). "Let us discuss math"; Effects of shift - problem lessons on mathematical discussions and level raising in early algebra. Mathematics Education Research Journal, 34(2), 8-25.

Creswell, J. W. (2012). Educational research: Planning, conducting, and evaluating quantitative and qualitative research (4th ed.). Pearson.

Ghofur, A., \& Rachma, E. A. (2021). Persepsi guru terhadap pembelajaran [Teacher's perception of learning]. SPEKTRA: Jurnal Kajian Pendidikan Sains, 2(2), 56-65. https://doi.org/10.37859/eduteach.v2i1.2365

Hendriana, H., Slamet, U. R., \& Utari Sumarmo. (2014). Mathematical connection ability and self-confidence (An experiment on junior high school students through contextual teaching and learning with mathematical manipulative). International Journal of Education, 8(1), 1-11.

Isfayani, E., Johar, R., \& Munzir, S. (2018). Peningkatan kemampuan koneksi matematis dan self-efficacy siswa melalui model pembelajaran kooperatif tipe rotating trio exchange (RTE) [Improving students' mathematical connection skills and self-efficacy through a rotating trio exchange (RTE) type cooperative learning model]. Jurnal Elemen, 4(1), 8092. https://doi.org/10.29408/jel.v4i1.473

Kamid, Rusdi, M., Fitaloka, O., Basuki, F. R., \& Anwar, K. (2020). Mathematical communication skills based on cognitive styles and gender. International Journal of 
Elementary school students' mathematical connection in problem-posing activities

Evaluation and Research in Education, 9(4), 847-856. https://doi.org/10.11591/ijere.v9i4.20497

Kar, T. (2016). Prospective middle school mathematics t teachers' knowledge of linear graphs in context of problem posing. International Electronic Journal of Mathematics Education, 8(6), 643-658.

Kartika, L., \& Tandililing, S. E. (2016). Penerapan engaged learning strategy dalam menumbuhkembangkan tanggung jawab belajar dan kemampuan koneksi matematis siswa sekolah menengah atas [Application of engaged learning strategy in developing learning responsibility and mathematical connection ability of high school students]. Jurnal Pendidikan Matematika Indonesia, 1(2), 57-64. https://doi.org/10.26737/jpmi.v1i2.84

Kenedi, A. K., Helsa, Y., Ariani, Y., Zainil, M., \& Hendri, S. (2019). Mathematical connection of elementary school students to solve mathematical problems. Journal on Mathematics Education, 10(1), 69-80. https://doi.org/10.22342/jme.10.1.5416.69-80

Maulyda, M. A., Erfan, M., Wulandari, N. P., Hidayati, V. R., \& Umar, U. (2020). The construction of mathematical communication schemes based on learning styles. Indonesian Research Journal in Education, 4(2), 413-432.

Metha, M., Pebriyanti, D., \& Karomah, N. (2018). The analysis of students' mathematical connection ability and responsibility in two stay two stray learning with problem cards. Unnes Journal of Mathematics Education, 7(3), 210-217.

Murdiyani, N. M., Ilma, R., Putri, I., Eerde, D. Van, \& Van, F. (2013). Developing a model to support students in solving subtraction. Journal on Mathematics Education, 4(1), 95-112. https://doi.org/10.22342/jme.4.1.567.95-112

Nägele, T., Weckwerth, W., Szymanski, J. J., \& Planck, M. (2014). Mathematical modeling reveals that metabolic feedback regulation of SnRK1 and hexokinase is sufficient to control sugar homeostasis from energy depletion to full recovery. Frontiers in Plant Science, 5(5), 1-11. https://doi.org/10.3389/fpls.2014.00365

Nurjaman, A., \& Sari, I. P. (2017). The effect of problem posing approach towards students' mathematical disposition, critical \& creative thinking ability based on school level. Journal Mathematics Education, 6(1), 69-76. https://doi.org/10.22460/infinity.v6i1.223

Prasetyo, A., Dwidayati, N. K., \& Junaedi, I. (2017). Students's mathematical connection ability and disposition reviewed by Keirsey personality type through eliciting activities mathematics learning. Unnes Journal of Mathematics Education, 6(2), 190-197.

Rahman, A., \& Ahmar, A. S. (2017). Posing of student's problem posing of high school mathematics students. Educational Process: International Journal, 6(1), 7-23. https://doi.org/10.22521/edupij.2017.61.1

Ramadhani, E. Y., \& Kusuma, A. B. (2020). Application of CORE learning to improve mathematical connection capabilities and self-efficacy. Mathematics Education Journal, 4(1), 54-62. https://doi.org/10.22219/mej.v4i1.11470

Rohendi, D., \& Dulpaja, J. (2013). Connected mathematics project (CMP) model based on presentation media to the mathematical connection ability of junior high school student. Journal of Education and Practice, 4(4), 17-22.

Rosyana, T., Afrilianto, M., \& Senjayawati, E. (2018). The strategy of formulate-share-listencreate to improve vocational high school students' mathematical problem posing ability and mathematical disposition on probability concept. Infinity: Journal of Mathematics Education, 7(1), 1-6. https://doi.org/10.22460/infinity.v7i1.p1-6

Sari, F. K., Chandra, T. D., \& Sudirman. (2018). Proses koneksi matematis siswa SMP dalam menyelesaikan soal cerita [The process of mathematical connection of junior high school students in solving story problems]. Jurnal Pendidikan: Teori, Penelitian, dan Pengembangan, 3(6), 715-722. 
Setiawan, F. T., Suyitno, H., \& Susilo, B. E. (2017). Analysis of mathematical connection ability and mathematical disposition students of 11 th grade vocational high school. Unnes Journal of Mathematics Education, 6(2), 152-162.

Solórzano, L. S. (2014). Problem-posing as a didactic resource in formal mathematics courses. Journal of Technology and Science Education, 5(2), 64-74. https://doi.org/10.3926/jotse. 141

The National Council of Teachers of Mathematics. (2000). Principles and standards for school mathematics. The National Council of Teachers of Mathematics, Inc.

Tsai, W.-H. (2007). Interactions between teaching norms of teacher's professional community and learning norms of classroom communities. Proceedings of the 31 Conference of the International Group for the Psychology of Mathematics Education, 4, $217-224$.

Urbaś, A. (2016). Mathematical description of a flexible connection of links and its applications in modeling the joints of spatial linkage mechanisms. Latin American Journal of Solids and Structures, 13(15), 2896-2921. https://doi.org/10.1590/1679-78252673

Yosopranata, D., Zaenuri, \& Mashuri. (2018). Mathematical connection ability on creative problem solving with ethnomathematics nuance learning model. Unnes Journal of Mathematics Education, 7(2), 108-113.

Young, C. J., Levine, S. C., \& Mix, K. S. (2018). The connection between spatial and mathematical ability across development. Frontiers in Psychology, 9(3), 138-147. https://doi.org/10.3389/fpsyg.2018.00755

Yuliani, R., Praja, E. S., \& Noto, M. S. (2018). Pengaruh model pembelajaran missouri mathematics project terhadap kemampuan koneksi matematis dan kemandirian belajar siswa SMP [The influence of the missouri mathematics project learning model on the mathematical connection ability and learning independence of junior high school students]. Jurnal Elemen, 4(2), 131-144. https://doi.org/10.29408/jel.v4i2.478 